\title{
Human Herpesvirus and the Immune Checkpoint PD-1/PD-L1 Pathway: Disorders and Strategies for Survival
}

\author{
Takayuki Murata
}

Citation: Murata, T. Human

Herpesvirus and the Immune Checkpoint PD-1/PD-L1 Pathway: Disorders and Strategies for Survival. Microorganisms 2021, 9, 778 .

https://doi.org/10.3390/

microorganisms 9040778

Academic Editor: David J. Allen

Received: 11 March 2021

Accepted: 6 April 2021

Published: 8 April 2021

Publisher's Note: MDPI stays neutral with regard to jurisdictional claims in published maps and institutional affiliations.

Copyright: (C) 2021 by the author. Licensee MDPI, Basel, Switzerland. This article is an open access article distributed under the terms and conditions of the Creative Commons Attribution (CC BY) license (https:// creativecommons.org/licenses/by/ $4.0 /)$.
Department of Virology and Parasitology, Fujita Health University School of Medicine, Toyoake 470-1192, Japan; tmurata@fujita-hu.ac.jp

\begin{abstract}
The immune system has evolved as a complex and efficient means of coping with extrinsic materials, such as pathogens and toxins, as well as intrinsic abnormalities, such as cancers. Although rapid and timely activation of the immune system is obviously important, regulated downregulation of the system is almost as significant as activation to prevent runaway immunity, such as allergies and hypercytokinemia. Therefore, the immune checkpoint programmed cell death 1 (PD-1)/programmed cell death ligand 1 (PD-L1) pathway is beneficial for the host. On the other hand, pathogens have evolved to evade host immunity by taking advantage of the PD-1/PD-L1 pathway. This review is focused on human herpesviruses, such as herpes simplex virus (HSV), cytomegalovirus (CMV), and Epstein-Barr virus (EBV), which cause various types of disorders, and their relationships with the PD-1/PD-L1 pathway. Understanding such relationships will be useful for developing preventative and therapeutic methods for disorders caused by herpesviruses.
\end{abstract}

Keywords: HSV; VZV; CMV; EBV; KSHV; PD-1; PD-L1

\section{Introduction}

Herpesviruses are large, enveloped viruses, with a large DNA genome contained within an icosahedral nucleocapsid. One of the best-known characteristics of herpesviruses is that they can establish lifetime latent infection in addition to lytic infection. During latency, herpesviruses remain silent, expressing only a subset of viral genes, and are hidden from host immunity. However, these viruses occasionally reactivate from latency into an active mode, in which almost all viral genes are expressed; viral DNA replication takes place; and, eventually, progeny virus particles are produced $[1,2]$.

The family of Herpesviridae is divided into three subfamilies: $\alpha-, \beta-$, and $\gamma$-herpesviruses [3]. The $\alpha$-herpesviruses typically grow faster than the members of the other subfamilies and, thereby, cause acute infectious illness. These viruses infect a relatively broad range of cells, including skin, mucosal, lymphoid, liver, spleen, neuronal, endothelial, and fibroblast cells, and establish latency in nerve ganglia. There are three human $\alpha$-herpesviruses: herpes simplex virus 1 (HSV-1), HSV-2, and varicella-zoster virus (VZV). HSVs cause herpes labialis, genital herpes, and herpes encephalitis, while VZV is responsible for chickenpox and shingles [4].

The $\beta$-herpesviruses have the largest genome (200-250 kb) among the Herpesviridae, and they have slower growth than the members of the other subfamilies. These viruses target epithelial, mucosal, lymphoid, liver, spleen, neuronal, endothelial, and fibroblast cells, especially under conditions where the host immune system is weak. They establish latency in myeloid and lymphoid cells, and/or their precursors. Cytomegalovirus (CMV) is a member of the human $\beta$-herpesviruses, which causes interstitial pneumonia, retinitis, and congenital cytomegalovirus infection, and has also been implicated in glioblastoma. Others include human herpesvirus 6A (HHV-6A), HHV-6B, and HHV-7, the latter two of which are causative agents of exanthema subitem in infants [5]. 
Epstein-Barr virus (EBV) and Kaposi sarcoma-associated herpesvirus (KSHV) are two members of the human $\gamma$-herpesviruses. Both viruses predominantly infect B cells, in which they occasionally establish latent infection. They can also infect other cell types, such as epithelial, mucosal, lymphoid, liver, spleen, endothelial, and fibroblast cells. It must be emphasized that these $\gamma$-herpesviruses have oncogenic properties. For example, EBV is associated with Burkitt's lymphoma (BL), Hodgkin's lymphoma (HL), post-transplant lymphoproliferative disorder (PTLD), diffuse large B cell lymphoma (DLBCL), natural killer (NK)/T cell lymphoma (NKTCL), gastric carcinoma (GC), and nasopharyngeal carcinoma (NPC), and KSHV is related to Kaposi sarcoma, Castleman disease, and primary effusion lymphoma [6].

Programmed cell death 1 (PD-1) is a type I membrane protein, initially identified as a gene involved in programmed cell death. PD-1 is a member of the immunoglobulin superfamily and is expressed as a monomer on the cell surface of not only activated T cells but also other immune cells, including B cells, NK cells, dendritic cells, and monocytes. The interaction of programmed cell death ligand 1 (PD-L1) with PD-1 activates the Src homology region 2-containing protein tyrosine phosphatase 2 (SHP2) signaling pathway. SHP2 downregulates signaling molecules in the $\mathrm{T}$ cell receptor pathway, such as Zetaassociated protein of $70 \mathrm{kDa}$, phosphatidylinositol 3-kinase, and phospholipase $\mathrm{C} \gamma 2$, and suppresses $\mathrm{T}$ cell activation. Fine-tuning of immunity by the PD-1/PD-L1 checkpoint provides advantages for the survival of the host, because an excessively strong immune response for a long period will have adverse health effects [7].

PD-L1 is expressed in hematopoietic cells, as well as endothelial, epithelial, fibroblast, and nerve cells. Cytokines, such as tumor necrosis factor- $\alpha$ (TNF- $\alpha)$, interferon- $\gamma$ (IFN- $\gamma$ ), and interleukin 4 (IL-4), upregulate expression of PD-L1 through signal transducer and activator of transcription (STAT) and nuclear factor- $\mathrm{KB}$ (NF- $\mathrm{kB}$ ) pathways and induce exhaustion of $\mathrm{CD}^{+} \mathrm{T}$ cell-mediated immunity (Figure 1). Transcription factors, such as hypoxia-inducible factor 1, myelocytomatosis (MYC), activator protein 1 (AP-1), and interferon regulatory factor (IRF), have been reported to play positive roles in PD-L1 expression. PD-L1 expression can also be increased by chromosomal abnormalities, such as translocation and focal amplification. Fusion of the PD-L1 locus with transcriptionally active gene loci may occur by translocation, leading to induction of $P D-L 1$ gene expression. Focal amplification involves increased copy number of the region including PD-L1. In addition, microRNAs (miRNAs), posttranslational modifications, degradation, and transportation of the protein play regulatory roles in its surface expression. When cancer cells overexpress PD-L1, the cells can elude $\mathrm{CD} 8^{+} \mathrm{T}$ cell-mediated cell killing because PD-L1 causes exhaustion of T cells by activating SHP2 signaling. This is one of the mechanisms by which cancer cells become resistant to tumor immunity. On the other hand, administration of PD-1/PD-L1 inhibitor can reactivate $\mathrm{CD} 8^{+} \mathrm{T}$ cell-mediated tumor immunity. Indeed, inhibitory antibodies against PD-1 or PD-L1 have shown excellent clinical effects in at least some types of cancer [8-11]. 


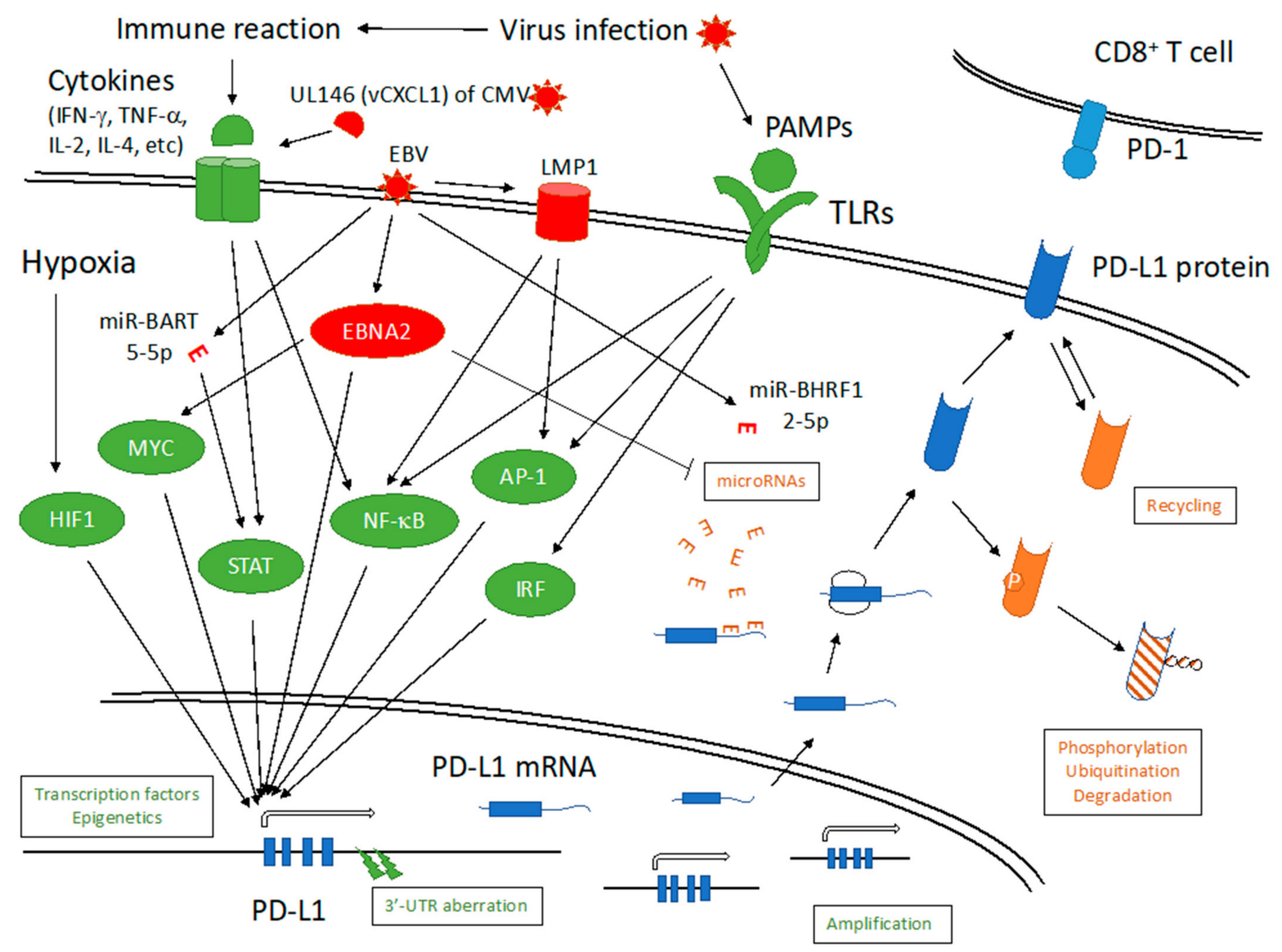

Figure 1. Schematic diagram of regulation of programmed cell death ligand 1 (PD-L1) gene expression. Green color indicates positive regulators, while orange denotes negative regulators. Red color indicates viral factors. IFN- $\gamma$, interferon- $\gamma$; TNF- $\alpha$, tumor necrosis factor- $\alpha$; IL-2, interleukin-2, CMV, cytomegalovirus; UL146, unique long 146; vCXCL1, viral chemokine (C-X-C motif) ligand 1; EBV, Epstein-Barr virus; LMP1, latent membrane protein 1; PAMPs, pathogen-associated molecular patterns; TLRs, toll-like receptors; HIF1, hypoxia-inducible factor 1; MYC, myelocytomatosis oncogene; STAT, signal transducer and activator of transcription; NF- $\mathrm{kB}$, nuclear factor- $\mathrm{KB}$; AP-1, activator protein 1; IRF, interferon regulatory factor, miR-BHRF1-2-5p, microRNA-BamHI H fragment rightward frame 1-2-5p.

Similar to the way in which cancer cells evade host tumor immunity by taking advantage of the PD-1/PD-L1 immune checkpoint, viruses also exploit this pathway. PD-L1 expression is induced by infection with influenza virus, human immunodeficiency virus, adenovirus, and Ebola virus [12,13]. As herpesviruses have complicated lifecycles and induce diverse symptoms and diseases, ranging from acute infection and inflammatory disorders to cancers, the mechanisms by which they evade the immune system are complex. This review article presents an overview of the relationships between each human herpesvirus and the PD-1/PD-L1 pathway that have been demonstrated in previous studies.

\section{HSV}

The relationship between HSV and the PD-1/PD-L1 pathway was first reported in the herpetic stromal keratitis mouse model in which ocular HSV-1 infection was shown to induce PD-1 and PD-L1 expression in T cells and macrophages, respectively, in the cornea and lymph nodes, and administration of an antagonistic antibody to PD-L1 aggravated keratitis [14]. These findings suggested that symptoms of herpetic stromal keratitis are ex- 
acerbated when the immune response is strong, and the PD-1/PD-L1 pathway ameliorates the disease by restraining the immune response. However, other reports indicated that HSV infection causes upregulation of PD-1/PD-L1, and increased PD-1/PD-L1 results in exhaustion of cell-mediated immunity, thereby increasing viral copy number. For example, blockade of PD-L1 by monoclonal antibody restored $\mathrm{CD} 8^{+} \mathrm{T}$ cell function in the ganglia in a mouse model of latent infection [15]. The latency-associated transcript of HSV-1 was also implicated in induction of PD-1/PD-L1 in the trigeminal ganglia tissue in a mouse model of latent infection, which was associated with exhaustion of $\mathrm{CD} 8^{+} \mathrm{T}$ cells and increased virus copy number $[16,17]$. PD-L1 levels were increased by HSV-1 infection in dendritic cells $[18,19]$ and epithelial cells of the cornea [20]. It has been speculated that PD-L1 induction may be mediated by inflammatory cytokines induced by virus infection, and pathogen-associated molecular patterns (PAMPs) may also be involved in induction of PD-L1 expression via Toll-like receptors (Figure 1).

In addition, HSV has been used as an oncolytic virus, and use of PD-1/PD-L1 pathway inhibitors in combination with oncolytic HSV was shown to result in increased antitumor immunity [21-23].

\section{VZV}

VZV infection causes dysregulation of PD-L1 levels in a cell type-dependent manner and was shown to downregulate PD-L1 protein expression in many types of cells, including fibroblasts [24]. As PD-L1 mRNA levels are not altered by VZV infection, the observed decrease in PD-L1 protein level is likely to be attributable to posttranscriptional regulation. The reduced level of PD-L1 expression by VZV resulted in higher levels of inflammation, which could contribute to the development of VZV-associated vasculopathy. On the other hand, peripheral blood mononuclear cells (PBMCs) expressed elevated levels of PD-L1 when infected with VZV and blocking of PD-L1 resulted in increased CD8 ${ }^{+} \mathrm{T}$ cell-mediated immunity [25]. These observations suggest that inhibition of the PD-1/PD-L1 pathway may enable efficient clearance of the virus in chickenpox and shingles. Other groups also reported that increased PD-L1 expression in macrophages resulted in impaired T cell activation and expansion, leading to a defective VZV-specific T cell immune response [26].

\section{CMV}

On infection with murine CMV, dendritic cells of mice showed elevated levels of PD-L1 expression, resulting in tolerance or anergy in antigen-specific T cells [27]. Antibodymediated blockade of the PD-1/PD-L1 pathway led to increased immune reaction in viremic CMV patients after renal transplantation [28]. A recent report [29] indicated that the unique long 146 (UL146) gene of CMV, which encodes a viral homolog of viral chemokine (C-X-C motif) ligand 1, augmented PD-L1 expression at both mRNA and protein levels in hepatocyte cell cultures through activation of STAT3 (Figure 1). Knockdown of PD-L1 reduced the effects of UL146 and upregulation of CD8 ${ }^{+} \mathrm{T}$ cell immunity. This may not be the only mechanism of PD-L1 induction by CMV, but the observation that a viral gene is involved in evading host immunity by upregulating PD-L1 expression is of interest. In addition, CMV has been shown to be associated with glioblastoma and, therefore, CMVspecific adoptive $\mathrm{T}$ cell therapy is currently being evaluated. Interestingly, the levels of PD-L1 expression in tumor cells were lower or even undetectable in glioblastoma patients who exhibited longer survival following $\mathrm{T}$ cell therapy against $\mathrm{CMV}$, suggesting that inhibition of the PD-1/PD-L1 pathway may be a promising treatment strategy, especially when combined with CMV-specific adoptive $\mathrm{T}$ cell therapy in glioblastoma patients.

\section{HHV-6A, 6B, and 7}

Infection of primary monocytes with HHV-6B upregulated surface expression of PDL1, which was likely to have been meditated by activation of reactive oxygen species (ROS) and STAT1/3 pathways [30]. Therefore, HHV-6/7 may also exploit the immune checkpoint pathway for survival. 


\section{EBV}

As EBV has oncogenic properties, the relationships of the PD-1/PD-L1 pathway and EBV or EBV-associated cancers have been studied extensively. Indeed, PD-1 and PD-L1 are expressed in many EBV-positive cancers, such as HL, PTLD, DLBCL, NPC, GC, and NKTCL, as well as chronic active Epstein-Barr virus infection (CAEBV), and in infiltrating immune cells [31-41]. PD-1/PD-L1 inhibitor products have already been approved or shown to have marked efficacy for treatment of several cancers, including HL, NKTCL, NPC, and GC [42-47]. EBV induces PD-L1 expression through multiple mechanisms (Figure 1). In NPC cells, EBV drives the expression of latent membrane protein 1 (LMP1) and IFN- $\gamma$, which in turn activate STAT, AP-1, and NF- $\mathrm{KB}$ pathways and induce PD-L1 [33]. Similarly, LMP1 activates AP-1 and NF- $\mathrm{BB}$ pathways and increases PD-L1 in NKTCL [48]. EBV nuclear antigen 2 (EBNA2) has also been linked with PD-L1 induction in B cells. It was reported that EBNA2 downregulated miR-34a through EBF-1 and induced PD-L1 in BL and DLBCL [49]. Our group presented evidence that EBNA2 acted as a transcriptional coactivator for PD-L1 by binding to enhancer sequences [50]. It is also possible that EBNA2 increases PD-L1 via induction of MYC gene expression [50]. In addition to miR-34a, a number of host-encoded miRNAs, such as miR-15, 200, and 513, play roles in regulation of PD-L1 [10]. It should also be noted that cancers, including those positive for EBV, frequently have aberrations in the $3^{\prime}$-untranslated region (UTR) of the PD-L1 gene in the genome $[36,38,39,51,52]$. This indicates that regulation of PD-L1 by miRNAs is very strong, and cells that acquire resistance to these miRNAs could evade host immunity by increasing PD-L1 expression and proliferate as cancers. Interestingly, EBV also encodes an miRNA (miR-BHRF1-2-5p) that negatively regulates PD-L1 expression through binding to the 3'-UTR of PD-L1 mRNA [53]. On the other hand, another study demonstrated that EBV miR-BART-5-5p downregulated PIAS3, a negative regulator of STAT, and thereby upregulated PD-L1 expression in GC [54]. These reports indicate that EBV has acquired many mechanisms of activating the PD-1/PD-L1 pathway for its survival.

\section{KSHV}

Another member of the $\gamma$-herpesvirus subfamily, KSHV, is also associated with some cancers, but its relationship with the PD-1/PD-L1 pathway has not been studied as extensively as EBV. There have been some reports of PD-L1-positive cancers that were infected with both EBV and KSHV [55,56]. Strong expression of PD-1 and PD-L1 were reported in KS specimens from AIDS patients [57]. In addition to cancers, KSHV can infect monocytes and macrophages and was shown to induce expression of PD-L1 [58,59]. Interestingly, lytic KSHV infection has been shown to increase PD-L1 expression [57,59]. Although the specific lytic gene of KSHV responsible for PD-L1 induction has not been identified, proinflammatory cytokines induced by lytic infection may in turn induce PD-L1, likely through NF-kB, STAT, and AP-1 signaling pathways [57,59].

\section{Conclusions}

Infection by herpesviruses can trigger an inflammatory response in the host, resulting in increased local cytokine/chemokine levels. Such cytokines and chemokines can induce expression of PD-1 and PD-L1, not only in infected cells but also in the surrounding cells through activation of NF- $\mathrm{KB}, \mathrm{STAT}$, IRF, and AP-1 signals. This is part of the host mechanism to restrain the runaway immunity, but if the degree of constraint is too strong, the host will not be able to kill the pathogen. Therefore, the host cells have established sophisticated systems to fine tune the PD-L1 level, such as miRNAs that play a role in regulating PD-L1 overexpression. Interestingly, EBV has already developed a countermeasure to the miRNA to evade immunity in that EBNA2 decreases miR-34a expression. Currently, only limited data are available regarding the precise molecular mechanisms by which herpesviruses manipulate the PD-1/PD-L1 pathway, but such mechanisms may be encoded by herpesviruses other than EBV because herpesviruses have many such genes and noncoding RNAs. Further studies are required, therefore, to elucidate these issues. 
Funding: This work was supported by grants-in-aid for Scientific Research form the Ministry of Education, Culture, Sports, Science and Technology (19K0750), Japan Agency for Medical Research and Development (AMED) (JP20wm0325012), and the Takeda Science Foundation.

Acknowledgments: I thank Hiroshi Kimura, Yoshitaka Sato, Yusuke Okuno, Yusuke Yanagi, Teru Kanda, Hironori Yoshiyama, and Tatsuya Tsurumi for discussions.

Conflicts of Interest: I declare no conflict of interest.

\section{References}

1. Grinde, B. Herpesviruses: Latency and reactivation-viral strategies and host response. J. Oral. Microbiol. 2013, 5, 5. [CrossRef]

2. Knipe, D.M.; Howley, P.M. Fields Virology, 6th ed; Wolters Kluwer/Lippincott Williams \& Wil-kins Health: Philadelphia, PA, USA, 2013.

3. Davison, A.J.; Eberle, R.; Ehlers, B.; Hayward, G.S.; McGeoch, D.J.; Minson, A.C.; Pellett, P.E.; Roizman, B.; Studdert, M.J.; Thiry, E. The order Herpesvirales. Arch. Virol. 2008, 154, 171-177. [CrossRef] [PubMed]

4. Levin, M.J.; Weinberg, A.; Schmid, D.S. Herpes Simplex Virus and Varicella-Zoster Virus. Microbiol. Spectr. 2016, 4, 135-156. [CrossRef]

5. Santos, C.A. Cytomegalovirus and other beta-Herpesviruses. Semin. Nephrol. 2016, 36, 351-361. [CrossRef] [PubMed]

6. Longnecker, R.; Neipel, F. Introduction to the human gamma-herpesviruses. In Human Herpesviruses: Biology, Therapy, and Immunoprophylaxis; Arvin, A., Campadelli-Fiume, G., Mocarski, E., Moore, P.S., Roizman, B., Whitley, R., Yamanishi, K., Eds.; Cambridge University Press: Cambridge, UK, 2007.

7. Sun, C.; Mezzadra, R.; Schumacher, T.N. Regulation and Function of the PD-L1 Checkpoint. Immunity 2018, 48, 434-452. [CrossRef] [PubMed]

8. Jiang, X.; Wang, J.; Deng, X.; Xiong, F.; Ge, J.; Xiang, B.; Wu, X.; Ma, J.; Zhou, M.; Li, X.; et al. Role of the tumor microenvironment in PD-L1/PD-1-mediated tumor immune escape. Mol. Cancer 2019, 18, 1-17. [CrossRef] [PubMed]

9. Prestipino, A.; Zeiser, R. Clinical implications of tumor-intrinsic mechanisms regulating PD-L1. Sci. Transl. Med. 2019, 11, eaav4810. [CrossRef] [PubMed]

10. Wang, Q.; Lin, W.; Tang, X.; Li, S.; Guo, L.; Lin, Y.; Kwok, H.F. The Roles of microRNAs in Regulating the Expression of PD-1/PD-L1 Immune Checkpoint. Int. J. Mol. Sci. 2017, 18, 2540. [CrossRef]

11. Wang, Y.; Wang, H.; Yao, H.; Li, C.; Fang, J.-Y.; Xu, J. Regulation of PD-L1: Emerging Routes for Targeting Tumor Immune Evasion. Front. Pharmacol. 2018, 9, 536. [CrossRef]

12. Mofrad, M.G.; Maleki, D.T.; Faghihloo, E. The roles of programmed death ligand 1 in virus-associated cancers. Infect. Genet. Evol. 2020, 84, 104368. [CrossRef]

13. Schönrich, G.; Raftery, M.J. The PD-1/PD-L1 Axis and Virus Infections: A Delicate Balance. Front. Cell. Infect. Microbiol. 2019, 9 , 207. [CrossRef]

14. Jun, H.; Seo, S.K.; Jeong, H.-Y.; Seo, H.-M.; Zhu, G.; Chen, L.; Choi, I.-H. B7-H1 (CD274) inhibits the development of herpetic stromal keratitis (HSK). FEBS Lett. 2005, 579, 6259-6264. [CrossRef]

15. Frank, G.M.; Lepisto, A.J.; Freeman, M.L.; Sheridan, B.S.; Cherpes, T.L.; Hendricks, R.L. Early CD4+T Cell Help Prevents Partial CD8+T Cell Exhaustion and Promotes Maintenance of Herpes Simplex Virus 1 Latency. J. Immunol. 2009, 184, 277-286. [CrossRef] [PubMed]

16. Allen, S.J.; Hamrah, P.; Gate, D.; Mott, K.R.; Mantopoulos, D.; Zheng, L.; Town, T.; Jones, C.; Von Andrian, U.H.; Freeman, G.J.; et al. The Role of LAT in Increased CD8+ T Cell Exhaustion in Trigeminal Ganglia of Mice Latently Infected with Herpes Simplex Virus 1. J. Virol. 2011, 85, 4184-4197. [CrossRef] [PubMed]

17. Chentoufi, A.A.; Kritzer, E.; Tran, M.V.; Dasgupta, G.; Lim, C.H.; David, C.Y.; Afifi, R.E.; Jiang, X.; Carpenter, D.; Osorio, N.; et al. The herpes simplex virus 1 latency-associated transcript promotes functional exhaustion of vi-rus-specific CD8+ T cells in latently infected trigeminal ganglia: A novel immune evasion mechanism. J. Virol. 2011, 85, 9127-9138. [CrossRef] [PubMed]

18. Bryant-Hudson, K.M.; Carr, D.J. PD-L1-expressing dendritic cells contribute to viral resistance during acute HSV-1 infection. Clin. Dev. Immunol. 2012, 2012, 924619. [CrossRef] [PubMed]

19. Channappanavar, R.; Twardy, B.S.; Suvas, S. Blocking of PDL-1 Interaction Enhances Primary and Secondary CD8 T Cell Response to Herpes Simplex Virus-1 Infection. PLoS ONE 2012, 7, e39757. [CrossRef]

20. Jeon, S.; Rowe, A.M.; Carroll, K.L.; Harvey, S.A.K.; Hendricks, R.L. PD-L1/B7-H1 Inhibits Viral Clearance by Macrophages in HSV-1-Infected Corneas. J. Immunol. 2018, 200, 3711-3719. [CrossRef]

21. Chen, C.-Y.; Wang, P.-Y.; Hutzen, B.; Sprague, L.; Swain, H.M.; Love, J.K.; Stanek, J.R.; Boon, L.; Conner, J.; Cripe, T.P. Cooperation of Oncolytic Herpes Virotherapy and PD-1 Blockade in Murine Rhabdomyosarcoma Models. Sci. Rep. 2017, 7, 1-10. [CrossRef]

22. Saha, D.; Martuza, R.L.; Rabkin, S.D. Macrophage Polarization Contributes to Glioblastoma Eradication by Combination Immunovirotherapy and Immune Checkpoint Blockade. Cancer Cell 2017, 32, 253-267.e5. [CrossRef]

23. Yamada, T.; Tateishi, R.; Iwai, M.; Koike, K.; Todo, T. Neoadjuvant use of oncolytic herpes virus G47Delta enhances the antitumor efficacy of radiofrequency ablation. Mol. Ther. Oncolytics 2020, 18, 535-545. [CrossRef] [PubMed] 
24. Jones, D.; Blackmon, A.; Neff, C.P.; Palmer, B.E.; Gilden, D.; Badani, H.; Nagel, M.A. Varicella-Zoster Virus Downregulates Programmed Death Ligand 1 and Major Histocompatibility Complex Class I in Human Brain Vascular Adventitial Fibroblasts, Perineurial Cells, and Lung Fibroblasts. J. Virol. 2016, 90, 10527-10534. [CrossRef] [PubMed]

25. Jones, D.; Como, C.N.; Jing, L.; Blackmon, A.; Neff, C.P.; Krueger, O.; Bubak, A.N.; Palmer, B.E.; Koelle, D.M.; Nagel, M.A. Varicella zoster virus productively infects human peripheral blood mononuclear cells to modulate expres-sion of immunoinhibitory proteins and blocking PD-L1 enhances virus-specific CD8+ T cell effector function. PLoS Pathog. 2019, 15, e1007650. [CrossRef] [PubMed]

26. Watanabe, R.; Shirai, T.; Namkoong, H.; Zhang, H.; Berry, G.J.; Wallis, B.B.; Schaefgen, B.; Harrison, D.G.; Tremmel, J.A.; Giacomini, J.C.; et al. Pyruvate controls the checkpoint inhibitor PD-L1 and suppresses T cell immunity. J. Clin. Investig. 2017, 127, 2725-2738. [CrossRef]

27. Benedict, C.A.; Loewendorf, A.; Garcia, Z.; Blazar, B.R.; Janssen, E.M. Dendritic Cell Programming by Cytomegalovirus Stunts Naive T Cell Responses via the PD-L1/PD-1 Pathway. J. Immunol. 2008, 180, 4836-4847. [CrossRef]

28. Sester, U.; Presser, D.; Dirks, J.; Gärtner, B.C.; Köhler, H.; Sester, M. PD-1 Expression and IL-2 Loss of Cytomegalovirus- Specific T Cells Correlates with Viremia and Reversible Functional Anergy. Arab. Archaeol. Epigr. 2008, 8, 1486-1497. [CrossRef]

29. Hu, L.; Wen, Z.; Chen, J.; Chen, Y.; Jin, L.; Shi, H.; Chen, J.; Chen, J. The cytomegalovirus UL146 gene product vCXCL1 promotes the resistance of hepatic cells to CD8+ T cells through up-regulation of PD-L1. Biochem. Biophys. Res. Commun. 2020, 532, 393-399. [CrossRef] [PubMed]

30. Romeo, M.A.; Montani, M.S.G.; Benedetti, R.; Giambelli, L.; D'Aprile, R.; Gaeta, A.; Faggioniab, A.; Cirone, M. The cross-talk between STAT1/STAT3 and ROS up-regulates PD-L1 and promotes the release of pro-inflammatory/immune suppressive cytokines in primary monocytes infected by HHV-6B. Virus Res. 2021, 292, 198231. [CrossRef]

31. Abe, H.; Kaneda, A.; Fukayama, M. Epstein-Barr Virus-Associated Gastric Carcinoma: Use of Host Cell Machineries and Somatic Gene Mutations. Pathobiology 2015, 82, 212-223. [CrossRef]

32. Romeo, M.A.; Montani, M.S.G.; Benedetti, R.; Giambelli, L.; D'Aprile, R.; Gaeta, A.; Faggioni, A.; Cirone, M. PD-L1 expression is characteristic of a subset of aggressive B-cell lymphomas and virus-associated malig-nancies. Clin. Cancer Res. 2013, 19, 3462-3473.

33. Fang, W.; Zhang, J.; Hong, S.; Zhan, J.; Chen, N.; Qin, T.; Zhang, L.; Tang, Y.; Zhang, Y.; Kang, S.; et al. EBV-driven LMP1 and IFN-gamma up-regulate PD-L1 in nasopharyngeal carcinoma: Implications for onco-targeted therapy. Oncotarget 2014, 5, 12189-12202. [CrossRef] [PubMed]

34. Green, M.R.; Monti, S.; Rodig, S.J.; Juszczynski, P.; Currie, T.; O’Donnell, E.; Chapuy, B.; Takeyama, K.; Neuberg, D.; Golub, T.R.; et al. Integrative analysis reveals selective 9p24.1 amplification, increased PD-1 ligand expression, and further induction via JAK2 in nodular sclerosing Hodgkin lymphoma and primary mediastinal large B-cell lymphoma. Blood 2010, 116, 3268-3277. [CrossRef] [PubMed]

35. Green, M.R.; Rodig, S.; Juszczynski, P.; Ouyang, J.; Sinha, P.; O’Donnell, E.; Neuberg, D.; Shipp, M.A. Constitutive AP-1 Activity and EBV Infection Induce PD-L1 in Hodgkin Lymphomas and Posttransplant Lymphoproliferative Disorders: Implications for Targeted Therapy. Clin. Cancer Res. 2012, 18, 1611-1618. [CrossRef] [PubMed]

36. Kataoka, K.; Miyoshi, H.; Sakata, S.; Dobashi, A.; Couronné, L.; Kogure, Y.; Sato, Y.; Nishida, K.; Gion, Y.; Shiraishi, Y.; et al. Frequent structural variations involving programmed death ligands in Epstein-Barr virus-associated lymphomas. Leukemia 2019, 33, 1687-1699. [CrossRef]

37. Kwon, D.; Kim, S.; Kim, P.-J.; Go, H.; Nam, S.J.; Paik, J.H.; Kim, Y.A.; Kim, T.M.; Heo, D.S.; Kim, C.W.; et al. Clinicopathological analysis of programmed cell death 1 and programmed cell death ligand 1 expression in the tumour microenvironments of diffuse large B cell lymphomas. Histopathology 2015, 68, 1079-1089. [CrossRef]

38. Okuno, Y.; Murata, T.; Sato, Y.; Muramatsu, H.; Ito, Y.; Watanabe, T.; Okuno, T.; Murakami, N.; Yoshida, K.; Sawada, A.; et al. Defective Epstein-Barr virus in chronic active infection and haematological malignancy. Nat. Microbiol. 2019, 4, 404-413. [CrossRef] [PubMed]

39. Sasaki, S.; Nishikawa, J.; Sakai, K.; Iizasa, H.; Yoshiyama, H.; Yanagihara, M.; Shuto, T.; Shimokuri, K.; Kanda, T.; Suehiro, Y.; et al. EBV-associated gastric cancer evades T-cell immunity by PD-1/PD-L1 interactions. Gastric Cancer 2019, 22, 486-496. [CrossRef]

40. Veloza, L.; Teixido, C.; Castrejon, N.; Climent, F.; Carrió, A.; Marginet, M.; Martinez, A. Clinicopathological evaluation of the programmed cell death 1 (PD1)/programmed cell death-ligand 1 (PD-L1) axis in post-transplant lymphoproliferative disorders: Association with Epstein-Barr virus, PD-L1 copy number al-terations, and outcome. Histopathology 2019, 75, 799-812. [CrossRef]

41. Xue, T.; Wang, W.-G.; Zhou, X.-Y.; Li, X.-Q. EBV-positive diffuse large B-cell lymphoma features PD-L1 protein but not mRNA overexpression. Pathology 2018, 50, 725-729. [CrossRef] [PubMed]

42. Goodman, A.; Patel, S.P.; Kurzrock, A.G.S.P.P.R. PD-1-PD-L1 immune-checkpoint blockade in B-cell lymphomas. Nat. Rev. Clin. Oncol. 2017, 14, 203-220. [CrossRef]

43. Johnson, D.; Ma, B.B.Y. Targeting the PD-1/PD-L1 interaction in nasopharyngeal carcinoma. Oral. Oncol. 2021, 113, 105-127. [CrossRef]

44. Joshi, S.S.; Maron, S.B.; Catenacci, D.V. Pembrolizumab for treatment of advanced gastric and gastroesophageal junction adenocarcinoma. Future Oncol. 2018, 14, 417-430. [CrossRef]

45. Merryman, R.W.; Armand, P.; Wright, K.T.; Rodig, S.J. Checkpoint blockade in Hodgkin and non-Hodgkin lymphoma. Blood Adv. 2017, 1, 2643-2654. [CrossRef] [PubMed] 
46. Suzuki, R. NK/T Cell Lymphoma: Updates in Therapy. Curr. Hematol. Malign-Rep. 2018, 13, 7-12. [CrossRef]

47. Takahara, T.; Satou, A.; Ishikawa, E.; Kohno, K.; Kato, S.; Suzuki, Y.; Takahashi, E.; Ohashi, A.; Asano, N.; Tsuzuki, T.; et al. Clinicopathological analysis of neoplastic PD-L1-positive EBV+ diffuse large B cell lymphoma, not otherwise specified, in a Japanese cohort. Virchows Archiv. 2021, 478, 541-552. [CrossRef]

48. Bi, X.W.; Wang, H.; Zhang, W.W.; Wang, J.H.; Liu, W.J.; Xia, Z.-J.; Huang, H.; Jiang, W.; Zhang, Y.; Wang, L. PD-L1 is upregulated by EBV-driven LMP1 through NF-kappaB pathway and correlates with poor prognosis in natural killer/T-cell lymphoma. J. Hematol. Oncol. 2016, 9, 109. [CrossRef]

49. Anastasiadou, E.; Stroopinsky, D.; Alimperti, S.; Jiao, A.L.; Pyzer, A.R.; Cippitelli, C.; Pepe, G.; Severa, M.; Rosenblatt, J.; Etna, M.P.; et al. Epstein-Barr virus-encoded EBNA2 alters immune checkpoint PD-L1 expression by downregulating miR-34a in B-cell lymphomas. Leukemia 2019, 33, 132-147. [CrossRef]

50. Yanagi, Y.; Okuno, Y.; Narita, Y.; Al Masud, H.A.; Watanabe, T.; Sato, Y.; Kanda, T.; Kimura, H.; Murata, T. RNAseq analysis identifies involvement of EBNA2 in PD-L1 induction during Epstein-Barr virus infection of primary B cells. Virology 2021, 557, 44-54. [CrossRef]

51. Kataoka, K.; Shiraishi, Y.; Takeda, Y.; Sakata, S.; Matsumoto, M.; Nagano, S.; Maeda, T.; Nagata, Y.; Kitanaka, A.; Mizuno, S.; et al Aberrant PD-L1 expression through 3'-UTR disruption in multiple cancers. Nature 2016, 534, 402-406. [CrossRef] [PubMed]

52. Shimada, K.; Yoshida, K.; Suzuki, Y.; Iriyama, C.; Inoue, Y.; Sanada, M.; Kiyoi, H. Frequent genetic alterations in immune checkpoint-related genes in intravascular large B-cell lympho-ma. Blood 2020, 137, 1491-1502. [CrossRef]

53. Cristino, A.S.; Nourse, J.; West, R.A.; Sabdia, M.B.; Law, S.C.; Gunawardana, J.; Gandhi, M.K. EBV microRNA-BHRF1-2-5p targets the 3'UTR of immune checkpoint ligands PD-L1 and PD-L2. Blood 2019, 134, 2261-2270. [CrossRef] [PubMed]

54. Yoon, C.J.; Chang, M.S.; Kim, D.H.; Kim, W.; Koo, B.K.; Yun, S.C.; Kim, S.H.; Kim, Y.S.; Woo, J.H. Epstein-Barr virus-encoded miR-BART5-5p upregulates PD-L1 through PIAS3/pSTAT3 modulation, wors-ening clinical outcomes of PD-L1-positive gastric carcinomas. Gastric Cancer 2020, 23, 780-795. [CrossRef] [PubMed]

55. Ronaghy, A.; Wang, H.-Y.; Thorson, J.A.; Medeiros, L.J.; Xie, Y.; Zhang, X.; Sheikh-Fayyaz, S. PD-L1 and Notch1 expression in $\mathrm{KSHV} / \mathrm{HHV}-8$ and EBV associated germinotropic lymphoproliferative disorder: Case report and review of the literature. Pathology 2017, 49, 430-435. [CrossRef]

56. Sanchez, S.; Veloza, L.; Wang, L.; López, M.; López-Guillermo, A.; Marginet, M.; Martínez, A.; Balagué, O.; Campo, E. HHV8positive, EBV-positive Hodgkin lymphoma-like large B cell lymphoma: Expanding the spectrum of HHV8 and EBV-associated lymphoproliferative disorders. Int. J. Hematol. 2020, 112, 734-740. [CrossRef]

57. Chen, J.; Del Valle, L.; Lin, H.Y.; Plaisance-Bonstaff, K.; Forrest, J.C.; Post, S.R.; Qin, Z. Expression of PD-1 and PD-Ls in Kaposi's sarcoma and regulation by oncogenic herpesvirus lytic reactiva-tion. Virology 2019, 536, 16-19. [CrossRef] [PubMed]

58. Montani, M.S.G.; Falcinelli, L.; Santarelli, R.; Granato, M.; Romeo, M.A.; Cecere, N.; Gonnella, R.; D’Orazi, G.; Faggioni, A.; Cirone, M. KSHV infection skews macrophage polarisation towards M2-like/TAM and activates Ire1 $\alpha$-XBP1 axis up-regulating pro-tumorigenic cytokine release and PD-L1 expression. Br. J. Cancer 2020, 123, 298-306. [CrossRef]

59. Host, K.M.; Jacobs, S.R.; West, J.A.; Zhang, Z.; Costantini, L.M.; Stopford, C.M.; Dittmer, D.P.; Damania, B. Kaposi's SarcomaAssociated Herpesvirus Increases PD-L1 and Proinflammatory Cytokine Expression in Human Monocytes. mBio 2017, 8, e00917-17. [CrossRef] [PubMed] 